\title{
Health functional literacy and adherence to antiretroviral therapy in people living with HIV
}

\author{
Letramento funcional em saúde e adesão a terapia \\ antirretroviral em pessoas vivendo com HIV
}

Letramiento funcional en salud y adherencia a la terapia antirretroviral en personas que viven con VIH

\author{
Taciane Alvarenga Perez ${ }^{\mathrm{a}}$ \\ Eduardo Federighi Baisi Chagas $\mathrm{s}^{\mathrm{a}, \mathrm{b}}$ \\ Osni Lázaro Pinheiro ${ }^{a}$
}

\section{How to cite this article:} Perez TA, Chagas EFB, Pinheiro OL Health functional literacy and adherence to antiretroviral therapy in people living with HIV. Rev Gaúcha Enferm. 2021:42:e20200012. doi: https://doi org/10.1590/1983-1447.2021.20200012 a Faculdade de Medicina de Marilia (FAMEMA). Marilia, São Paulo, Brasil.

Universidade de Marilia (UNIMAR). Marilia, São Paulo, Brasil.

\section{ABSTRACT}

Objective: To verify the relationship between adherence to antiretroviral therapy and Functional Health Literacy.

Methods: Cross-sectional study, carried out in the Specialized Care Service in 2019, using questionnaires about adherence to treatment and Functional Health literacy people living with human immunodeficiency virus. The LFS questionnaire has questions about numerical and text interpretation skills and the adherence questionnaire addresses how to use antiretrovirals. Viral load was verified by analysis of medical records. Associations between variables were analyzed using the Chi-square test.

Results: 78 patients were interviewed and a significant association between the variables to treatment adherence and Functional Literacy in Health was observed. The association between adherence to therapy and viral load levels was also significant.

Conclusions: The data found show a significant association between the variables, ie, the lower the functional health literacy, the greater the difficulty to adhere to treatment.

Keywords: Health literacy. Medication adherence. Antiretroviral therapy, highly active.

\section{RESUMO}

Objetivo: Verificar a relação entre adesão a terapia antirretroviral e o Letramento Funcional em Saúde.

Métodos: Estudo transversal, realizado no Serviço de Atendimento Especializado, em 2019, utilizando questionários sobre adesão ao tratamento e Letramento Funcional em Saúde em pessoas vivendo com o Vírus da Imunodeficiência Humana. 0 questionário para LFS possui questões sobre habilidades numéricas e de interpretação de texto e o de adesão aborda a forma de utilização dos antirretrovirais. A carga viral foi obtida nos prontuários. As associações entre as variáveis foram analisadas pelo teste do Qui-quadrado. Resultados: Foram entrevistados 78 pacientes e observada uma associação significativa entre as variáveis adesão ao tratamento e Letramento Funcional em Saúde. A associação entre a adesão à terapia e níveis de carga viral também foi significativa.

Conclusões: Os dados encontrados mostram associação significativa entre as variáveis, então, quanto menor o letramento funcional em saúde, maior a dificuldade de aderir ao tratamento.

Palavras-chave: Letramento em saúde. Adesão à medicação. Terapia antirretroviral de alta atividade.

\section{RESUMEN}

Objetivo: Verificar la asociación entre adherencia a la terapia antirretroviral y el Letramiento Funcional en Salud.

Métodos: Estudio transversal, realizado en un Servicio de Atendimiento Especializado en 2019, utilizando cuestionarios sobre adherencia al tratamiento y el Letramiento Funcional en Salud en personas que viven con virus de inmunodeficiencia humana. El cuestionario LFS tiene preguntas sobre habilidades numéricas e interpretación de textos y el cuestionario de adherencia aborda el uso de antirretrovirales. La carga viral se verificó mediante análisis de las historias clínicas. Las asociaciones entre variables se analizaron mediante la prueba de Qui-cuadrado.

Resultados: Fueron entrevistados 78 pacientes e observada una asociación significativa entre las variables adherencia al tratamiento y Letramiento Funcional en Salud. La asociación entre la adherencia a la terapia y niveles de carga viral también fue significativa. Conclusiones: Los datos encontrados muestran una asociación significativa entre las variables, es decir, cuanto menor el Letramiento Funcional em Salud, mayor es la dificultad para adherirse al tratamiento.

Palabras clave: Alfabetización en salud. Cumplimiento de la medicación. Terapia antirretroviral altamente activa. 


\section{口INTRODUCTION}

The Human Immunodeficiency Virus (HIV) is a retrovirus that infects and leads to the death of cells of the immune system due to a specific tropism for CD4+T lymphocytes. This type of viral reproduction causes immunological deficiency, characteristic of the disease ${ }^{(1)}$.

Currently, HIV represents a major public health problem since, in the last 30 years, the epidemic of the disease has brought serious consequences for several families and society. However, its transmission has had a global decline, which may be related to prevention and treatment programs ${ }^{(2)}$.

In the Brazilian Epidemiological Bulletin of HIV/AIDS, referring to the period from 2007 to June 2019,300,496 cases of HIV infection in Brazil were recorded. Among these, 136,902 (45.6\%) cases were recorded in the Southeast,60,470 (20.1\%) in the South, 55,090 (18.3\%) in the Northeast,26,055 (8.7\%) in the North and 21,979 (7.3\%) in the Midwest region ${ }^{(3)}$.

The United Nations has created the goal 90-90-90, which aims to help ending the AIDS epidemic around the world. This goal proposes that by $2020,90 \%$ of people with the virus are aware of their diagnosis, $90 \%$ of people have continuous access to antiretroviral therapy and $90 \%$ of people being treated have an undetectable viral load ${ }^{(2)}$.

The advancement in health technologies has enabled a change in the profile of the disease, which used to be associated with early death and now has a chronic character, enabling the patient to live better and with the disease for a longer time ${ }^{(1)}$. In Brazil, antiretroviral therapy (ART) is universal and free in the Unified Health System (UHS), known as Sistema Único de Saúde (SUS), being considered a reference in the world, as a model of access to HIV therapy ${ }^{(4)}$.

Antiretroviral therapy aims to suppress the virus, in addition to strengthening the immune system, thus preventing the occurrence of opportunistic diseases. The main objective is to achieve plasma levels of undetectable viral load, improving quality of life, in addition to increasing the life expectancy of people with the virus( ${ }^{(4)}$.

The effectiveness of antiretroviral therapy for the human immunodeficiency virus is a well-established fact in the scientific community, however, the effectiveness is dependent on the patients' adherence to treatment ${ }^{(5-6)}$. In order to achieve undetectable viral load levels, studies point out the importance of high adherence to ART, reaching at least $80 \%$ of adherence ${ }^{(5)}$.

The adherence to treatment is a complex process, involving sociodemographic, clinical and behavioral aspects, which responsibility involves patients, the health service and the support network. Besides, in adherence to ART, the challenge is even bigger, as it involves fighting the disease epidemic ${ }^{(7)}$.
The absence or low adherence to treatment can cause failures in the control of the disease, once the virus can become resistant to drugs. This situation may lead to the need for more complex therapeutic plans that may require the use of a greater number of medications ${ }^{(5)}$.

There are several ways to check the patient's adherence to treatment. Among them, it is highlighted the register of dispensing pharmacies in specialized centers, analysis of medical records, self-reports on medication control and questionnaires developed and validated to evaluate adherence to $\mathrm{ART}^{(8)}$.

For the patient to adequately perform his health care, it is necessary that he understand their illness as well as the proposed health interventions. Therefore, patients who have difficulties in understanding health information, may have flaws in adherence to the proposed pharmacological treatment. A resource to check a patient's cognitive potential in understanding the health information provided by health professionals, is the assessment of their Functional Health Literacy $(\mathrm{FHL})^{(9)}$.

Functional Health Literacy can be understood as the set of skills to understand, evaluate and put health care guidelines into practice. Several factors may be involved with health literacy, such as socioeconomic conditions and educational level(9).

The level of the patient's understanding in relation to the information he receives from health professionals about his treatment represents a factor that is likely to interfere with adherence to the use of antiretrovirals. Therefore, the hypothesis of this study is that inadequate levels of Functional Health Literacy in patients living with HIV may be associated with low adherence to treatment with antiretrovirals.

Thus, the goal of the present study was to verify the relation between adherence to antiretroviral therapy and Functional Health Literacy.

\section{METHODS}

This is a cross-sectional study, with data collection on treatment adherence and Functional Health Literacy in a prospective way and retrospective verification of viral load, through analysis of medical records.

The sample was selected by convenience, composed by individuals who follow up at the Specialized assistance service (Serviço de Atendimento Especializado - SAE) in Marília County, SP. This service serves a population of approximately 400 patients living with HIV in the county, in addition to other pathologies, such as hepatitis $C$ and syphilis. The service features a multidisciplinary team, with an infectious disease physician and general practitioner, psychologist, 
social worker, pharmacist and nursing staff. The nursing team is responsible for managing the service, in addition to providing direct assistance to the patient, with consultations and clarification of doubts.

The individuals were invited to participate when they were to attend the service days of medical consultation or to perform laboratory tests.

The study included individuals over 18 years old, with a previous diagnosis of HIV and who had been on ART for at least 3 months. Individuals belonging to the population deprived of their liberty were excluded, due to the need for special security schemes for the application of the questionnaire.

The minimum sample size was estimated at 75 individuals to analyze the association between two qualitative variables, considering for the calculation (software G*Power, version 3.1.9.2, Franz Faul, Universität Kiel, Germany) a margin of type I error of 5\%, a study power of 95\%, 4 degrees of freedom and an average effect size (0.5).

The data were collected from April to August 2019, through the application of treatment adherence questionnaires and Functional Health Literacy. During the application, the researcher was close to the patient, providing guidelines for filling out and clarifying doubts. If the user had difficulty reading, the questionnaire was presented verbally by the interviewer, without any influence on the interviewee. The approximate time for data collection was 30 minutes.

The viral load data were obtained through the Logistics Control System for Medicines, known as Sistema de Controle Logístico de Medicamentos (SICLOM), accessed directly at the Specialized Service. The result of the laboratory exam closest to the date of the interview of each participant was used, without exceeding the six-month period, which represents the interval generally recommended for patients to perform their exams. Viral load was considered undetectable when the "polymerase chain reaction" (PCR) technique resulted in $<50$ copies/ml of blood ${ }^{(10)}$.

The Functional Health Literacy test used represents a cross-cultural adaptation to the Brazilian Portuguese language of the "Test of Functional Health Literacy in Adults - TOFHLA" of North American origin ${ }^{(11)}$.

This questionnaire includes a set of questions that assess the patient's ability to work with health information that involves numbers and another group of questions that are related to the comprehension of the text ${ }^{(11)}$.

The numerical stage of the questionnaire consists of a series of cards with various information, such as scheduling appointments and results of laboratory tests, on which the participant will rely on to answer a series of questions. At this stage, the participant could score from 0 to 17 points.
To transform the score on a scale from 0 to 50 , the original TOFHLA weighted score table was used, which means that the number of correct answers was multiplied by 2.94 (correction factor) ${ }^{(11)}$.

The stage of reading and understanding text, presented three texts: A (16 items), B (20 items) and C (14 items). These texts presented four alternatives for the participants to choose one of the options available $e^{(11)}$.

For each question of text comprehension, a score of 1 was assigned for correct answer and 0 for incorrect answer. When the participant left the question blank or checked more than one alternative, it scored 0 . was assigned. The maximum value for this stage of the questionnaire was 50 points ${ }^{(11)}$.

This way, the sum of the numerical items and the text comprehension items totals 100 points. The classification of Functional Health Literacy is made using the following criteria: inadequate (up to 59 points); limited (60 to 74 ) and adequate (75 to 100)(11).

The FHL test used in this study also included questions about quality of life and reading habits, however, these data were not scored for the classification of the degree of health literacy of the research participants, but were used to characterize the sample studied.

To evaluate patients' adherence to antiretroviral therapy, the "Questionnaire for Assessment of Adherence to Antiretroviral Treatment (CEAT-HIV) was used and tested and validated. This tool is multidimensional, seen that it addresses the main factors that can influence adherence to antiretroviral treatment ${ }^{(8)}$

The questionnaire consists of 20 questions, of which 17 (questions 1 to 4 and 6 to 18) have a Likert-type scale with five alternatives, with a higher score on the scale, indicating a greater degree of adherence to treatment. This way, in this group of questions it is possible to reach 85 points ${ }^{(8)}$.

In question 5, the score ranges from zero to two points, being zero for the patient who doesn't know the name and dose of the antiviral used, one point when the patient knows only one of the informations and two points when the answer is complete. In questions 19 and 20, the score ranges from zero to one point per question, with negative answers in question 19 and affirmative in question 20 receiving a score of 1. The complete questionnaire allows a minimum score of 17 and a maximum of 89 points ${ }^{(8)}$.

The degree classification of adherence to treatment follows the following criteria: Insufficient ( $\leq 74$ points), Adequate (75 to 79 points) and Strict ( $\geq 80$ points) ${ }^{(8)}$.

The quantitative variables were described by means and 95\% confidence intervals $(95 \% \mathrm{Cl})$ and qualitative variables by absolute $(\mathrm{N})$ and relative (\%) frequency distribution. Differences in the frequency distribution for qualitative variables 
were analyzed using the Chi-square test for proportion. Associations between qualitative variables were analyzed using the Chi-square test for association. The normality distribution was verified by the Kolmogorov-Smirnov test. The data were analyzed using the SPSS software (version 19.0) and the significance level adopted was $5 \%$ ( $p$-value $\leq 0.05$ ).

The participants signed the Free and Informed Consent Form (ICF) in two copies. The work was authorized by the Municipal Health Office of Marília - SP and by the Ethics Committee of the Faculty of Medicine of Marilia (FAMEMA) of São Paulo, under number CAAE: 09097019.3.0000.541 and statement No.3,241,437.

\section{RESULTS}

In general, the participants in this study showed a slight predominance of males (51.2\%), with an average age of approximately 45 years and schooling covering mainly complete high school (46.2\%), but also with some individuals (2.6\%) having completed their adult literacy. Around $23.1 \%$ of the participants reported having completed higher education. This information is described in Chart 1, which also shows other variables analyzed in this study.

Regarding the $\mathrm{FHL}$, it was found that only $10.2 \%$ of the population had adequate literacy, with the others classified as inadequate (68\%) and limited (21.8\%). These data are described in Table 1.

The variables gender, age, schooling, quality of life and reading habits were not significantly associated with the FHL. Regarding education, it is worth noting that even individuals with complete higher education did not necessarily present fully satisfactory results in relation to the FHL (Table 1).

However, an association cited ( $p \leq 0.05)$ was observed between the variables adherence to ART and the level of Functional Literacy in Health of the participants. In this sense, among patients with distorted FHL (68\%), the majority (51.3\%) had an insufficient adherence to antiretroviral treatment (Table 1).

Another important aspect shown in this study was the patients' adherence to treatment with antiretrovirals. This assessment was made using the CEAT-HIV questionnaire, which identified only a small part of the population (15.4\%) with strict adherence to treatment, that is, with strict use of their medications (Table 1).

Thus, the majority of participants showed failures in adhering to treatment, being characterized as adequate (25.6\%) or insufficient (59\%).

The present study also verified, through the analysis of medical records, the viral load of patients who answered the questionnaires. As previously mentioned, these data referred to the last exams made before the date of the interview. Data from patients whose examination had been performed more than six months ago were not used. Thus, among the 78 participants, 63 fulfilled this criterion, therefore, there was a loss of data in relation to the viral load of 19.3\% (missing data).

The timing between the performance of the exam to check the viral load and the application of the questionnaires used in this study was $3.0 \pm 0.75$ months, ranging from 1.43 to 4.96 months.

Most of the participants (61.9\%) showed an undetectable viral load, however, the proportion of those with a viral load above 50 copies / $\mathrm{ml}$ of blood (38.1\%) deserves attention, which may suggest problems in adhering to treatment. It should be noted that among these, none had adequate Functional Health Literacy, as well as strict adherence to treatment (Tables 1 and 2, respectively).

\section{DISCUSSION}

Antiretroviral therapy has been offered universally and free of charge by the Unified Health System since 1996, however, adherence to treatment, which is of fundamental importance for the control of viral load, is still a major obstacle in health services ${ }^{(2,4)}$. Therefore, the present study analyzed the relationship between FHL and adherence to antiretroviral therapy.

Most of the participants in this study were aged over 40 years, differing from the national profile, which according to the Brazilian Epidemiological Bulletin of HIV/AIDS, published in 2019, shows that most cases of infection are in individuals aged 20 to 34 years ${ }^{(3)}$.

One of the most relevant results found in the present study was the high percentage of patients with insufficient adherence to ART (59\%). In a similar study made in 2017, which used the same questionnaire to assess adherence, the results were even more alarming, with $80.7 \%$ of its sample, showing insufficient adherence to treatment ${ }^{(12)}$. A similar result was obtained in another study, in which the sample had an insufficient level of adherence in $70.3 \%$ of the interviewed patients ${ }^{(13)}$.

Adherence is one of the biggest challenges of the multiprofessional team involved in the care of patients living with $H I V$, since it involves sociodemographic, clinical, behavioral aspects and the co-responsibility of users, health service and support network ${ }^{(4,7)}$.

Factors such as income and education level also directly influence adherence to antiretroviral therapy. In the studies mentioned above, the researchers reported that a higher level of education favored the understanding of their health status and drug therapy ${ }^{(12-13)}$. 
Table 1 - Analysis of the association between Functional Health Literacy and sociodemographic variables, quality of life, reading habits, adherence to antiretroviral treatment and viral load.

\begin{tabular}{|c|c|c|c|c|c|}
\hline \multirow{2}{*}{ Variable } & \multirow{2}{*}{ Category } & \multicolumn{3}{|c|}{ Functional Health Literacy } & \multirow{2}{*}{ "p value" } \\
\hline & & Limited & Inadequate & Adequate & \\
\hline \multirow{2}{*}{ Gender $(n=78)$} & Male & $9(11.5)$ & $24(30.8)$ & $7(8.9)$ & 0.288 \\
\hline & Female & $8(10.3)$ & $29(37.2)$ & $1(1.3)$ & \\
\hline \multirow{3}{*}{ Age } & 18 to 39 years & $8(10.3)$ & $19(24.3)$ & $2(2.6)$ & 0.601 \\
\hline & 40 to 59 years & $5(6.4)$ & $24(30.8)$ & $3(3.8)$ & \\
\hline & $\geq 60$ years & $4(5.1)$ & $10(12.8)$ & $3(3.8)$ & \\
\hline \multirow{5}{*}{$\begin{array}{l}\text { Schooling } \\
\quad(n=78)\end{array}$} & Elementary school & $3(3.8)$ & $5(6.4)$ & $0(0.0)$ & 0.738 \\
\hline & Middle school & $0(0.0)$ & $14(17.9)$ & $0(0.0)$ & \\
\hline & High School & $10(12.8)$ & $24(30.8)$ & $2(2.6)$ & \\
\hline & Adult literacy & $0(0.0)$ & $2(2.6)$ & $0(0.0)$ & \\
\hline & Higher Education & $4(5.1)$ & $8(10.3)$ & $6(7.7)$ & \\
\hline \multirow{5}{*}{$\begin{array}{l}\text { Life Quality } \\
\qquad(\mathrm{n}=78)\end{array}$} & Excellent & $3(3.8)$ & $5(6.4)$ & $0(0.0)$ & 0.874 \\
\hline & Very good & $8(10.3)$ & $21(26.9)$ & $2(2.6)$ & \\
\hline & Good & $5(6.4)$ & $14(18.0)$ & $5(6.4)$ & \\
\hline & Regular & $0(0.0)$ & $11(14.0)$ & $0(0.0)$ & \\
\hline & Bad & $1(1.3)$ & $2(2.6)$ & $1(1.3)$ & \\
\hline \multirow{3}{*}{$\begin{array}{l}\text { Reading } \\
(n=78)\end{array}$} & Pleasure & $10(12.8)$ & $25(32.1)$ & $7(8.9)$ & 0.556 \\
\hline & Reads for obligation & $0(0.0)$ & $1(1.3)$ & $0(0.0)$ & \\
\hline & Doesn't like & $7(8.9)$ & $27(34.7)$ & $1(1.3)$ & \\
\hline \multirow{4}{*}{$\begin{array}{l}\text { Frequency } \\
\text { of reading } \\
\quad(n=78)\end{array}$} & Everyday & $11(14.1)$ & $25(32.1)$ & $7(8.9)$ & 0.679 \\
\hline & Once in a week & $3(3.8)$ & $12(15.4)$ & $0(0.0)$ & \\
\hline & Reads at work & $0(0.0)$ & $2(2.6)$ & $0(0.0)$ & \\
\hline & Never reads & $3(3.8)$ & $14(18.0)$ & $1(1.3)$ & \\
\hline \multirow{3}{*}{$\begin{array}{l}\text { Adherence } \\
\quad(n=78)\end{array}$} & Insuficient & $6(7.7)$ & $40(51.3)$ & $0(0.0)$ & $0.001^{*}$ \\
\hline & Adequate & $7(8.9)$ & $13(16.7)$ & $0(0.0)$ & \\
\hline & Strict & $4(5.1)$ & $0(0.0)$ & $8(10.3)$ & \\
\hline \multirow{2}{*}{$\begin{array}{l}\text { Viral Load } \\
\qquad(n=63)\end{array}$} & Indetectable & $9(14.3)$ & $22(34.9)$ & $8(12.7)$ & $0.046^{*}$ \\
\hline & Detectable & $5(7.9)$ & $19(30.2)$ & $0(0.0)$ & \\
\hline
\end{tabular}

Source: Research data, 2019.

* Chi-square test for $p$-value $\leq 0.05$. 
Table $\mathbf{2}$ - Analysis of the association between adherence to antiretroviral treatment and viral load.

\begin{tabular}{|c|c|c|c|c|c|}
\hline \multirow[b]{2}{*}{ Variable } & \multirow[b]{2}{*}{ Category } & \multicolumn{3}{|c|}{ Adherence } & \multirow[b]{2}{*}{ p-value } \\
\hline & & $\begin{array}{c}\text { Insuficient } \\
\text { n (\%) }\end{array}$ & $\begin{array}{c}\text { Adequate } \\
\text { n (\%) }\end{array}$ & $\begin{array}{l}\text { Strict } \\
\text { n (\%) }\end{array}$ & \\
\hline \multirow{3}{*}{ Load Viral } & Indetectable & $17(27.0)$ & $10(15.9)$ & $12(19.0)$ & \multirow{3}{*}{$0,004^{*}$} \\
\hline & & & & & \\
\hline & Detectable & $19(30.2)$ & $5(7.9)$ & $0(0.0)$ & \\
\hline
\end{tabular}

Source: Research data, 2019.

* Chi-square test for $p$-value $\leq 0.05$.

In the present study, the investigation regarding the influence of the patient's cognitive aspects on adherence to antiretroviral treatment was not restricted to the analysis of the variable related to the participant's level of education, but expanded the concept, through the $\mathrm{FHL}$, which verifies the understanding of the patient when receiving information directed to the health area.

Therefore, the patient may have a higher level of education, however, not necessarily present the necessary skills to enable their health care ${ }^{(11)}$.

To illustrate this conception that involves schooling and understanding of health-related information, the current study presented a sample with approximately $23.1 \%$ of the participants having completed a higher education course, however, only $7 \%$ of these considered the $\mathrm{FHL}$ adequate.

An important data regarding the population of the present study is that only $10 \%$ of the participants had an adequate level of FHL, that is, a small minority reached maximum scores.

These results differ from those found in a recently published national study, using TOFHLA, which is the instrument used in the present study ${ }^{(11)}$. According to this study, 54.6\% of participants were categorized with adequate $\mathrm{FHL}, 26.2 \%$ in the inadequate category and $19.2 \%$ as limited. However, an important aspect is that the sample of this study was intentionally constituted with contingent of education, with the purpose of representing the different educational layer found in the Brazilian population.

In addition to the questions that directly assess the $\mathrm{FHL}$, TOFLHA also shows questions about reading habits and quality of life. Most participants in this study positively evaluated their quality of life and pointed out that they read for pleasure.

In general, the literature presents a greater number of studies that seek to establish associations between FHL and certain diseases such as depression, asthma, renal failure and several other situations. On the other hand, there is a scarcity of studies that relate FHL with quality of life in the general population, that is, without the presence of diseases.
Studies of this nature may be useful in promoting health and not only in the rehabilitation of pathological conditions already found ${ }^{(14)}$.

The variable adherence to ART and the degree of FHL showed a statistically significant association. It was observed that all patients with adequate FHL had strict adherence to treatment, while the vast majority of patients with inadequate $\mathrm{FHL}$ had insufficient adherence to treatment.

These data represent the main aspects of the present study, as the hypothesis initially established was precisely the existence of a relationship between the low performance of the patient in the instrument that evaluates the FHL and the low adherence to drug treatment.

In a study conducted in two American cities, the association between FHL and health care with patients living with HIV was investigated. In this research, it was evidenced that most of the people interviewed had low FHL and did not have an adequate adherence to treatment, since they interrupted the use of medications on holidays or to use alcohol and other chemicals(15).

A similar result was obtained in a study that verified the FHL in patients living with HIV, using a questionnaire with open questions about knowledge on HIV and the importance of adhering to treatment ${ }^{(16)}$. In this study, it was found that patients with inadequate or limited FHL had difficulties in reporting their health status and doubts to the doctor, compromising their communication and, consequently, their health care ${ }^{(16)}$.

When antiretroviral treatment is correctly prescribed and administered, the viral load will reach levels considered undetectable, increasing life expectancy and quality and reducing the mortality rate ${ }^{(17)}$.

In the present study, it was found that among the participants with detectable viral load, none reached the highest FHL score. These data corroborate those found in a study conducted in 2014, which showed an association between $\mathrm{FHL}$ and adherence to ART, with a consequent reduction in viral load levels ${ }^{(18)}$. 
An important result, shown in this study, was the relationship between adherence to antiretroviral therapy and levels of viral load, since all participants who had a strict adherence level had undetectable viral load levels, while the majority of patients with insufficient adherence had viral load detectable.

A similar result occurred in another study, in which viral load and number of CD4+ T lymphocytes showed a significant association with the highest degrees of treatment adherence ${ }^{(19)}$.

To achieve undetectable viral load levels, studies point out the importance of high adherence to ART, reaching at least $80 \%$ of adherence ${ }^{(5)}$. In addition, the UN goal is that $90 \%$ of people have continuous access to antiretroviral therapy and $90 \%$ of people being treated have an undetectable viral load ${ }^{(2)}$.

All of this information reinforces that adherence to antiretroviral treatment is essential for better control of the pathology. In this sense, the patient's knowledge about their disease and also about the importance of pharmacological treatment are essential for the success of therapy.

It is worth mentioning that in the present study, strict adherence to treatment reached only $15.4 \%$ of the participants, therefore, rates well below those mentioned above, which reinforces the need for educational health actions for this population.

In general, the health information transmitted by health professionals is complex and difficult to understand, especially for individuals with low FHL. In a systematic review, it was found that adequate health literacy is essential for proper treatment follow-up ${ }^{(20)}$.

The FHL represents a relatively recent topic in research, with few studies carried out, mainly in Brazil. In the case of research of this nature in patients living with HIV, the theme is even more deserving of attention ${ }^{(20)}$.

Although there are national studies that verify adherence to ART, they do not investigate its association with FHL. Although there are international studies that verify the FHL in patients living with HIV, it is important to emphasize that this theme suffers a very intense cultural influence, justifying its reproduction in different contexts, especially those related to the location.

The verification of the FHL is extremely important to recognize the ways in which health information is transmitted to patients, as they can directly influence the success of HIV therapy. The communication process of the multiprofessional team, as well as the monitoring of adherence, must be permanently evaluated by the health team.

\section{- CONCLUSION}

The present study, using instruments previously validated for the Brazilian population, made it possible to assess adherence to antiretroviral treatment and the FHL of people living with HIV, in a specialized care service. The use of instruments previously validated with the Brazilian population represents a strength of this study, however, one difficulty found was the time of application of the questionnaire on $\mathrm{FHL}$, usually around 25 minutes, thus requiring the cooperation of the participant.

It was possible to verify that a large part of the sample had a low adherence to treatment and also an insufficient FHL. In addition, the relationship between adherence to treatment and viral load was observed, and patients who had high adherence kept their viral load levels undetectable.

Together, these data reinforce the importance of the patient living with HIV presenting an adequate adherence to drug treatment so that there is a better control of viral load. However, for this it is necessary that information about your health status and about the correct use of antiretrovirals be properly assimilated.

For this, it is important to consider the context unveiled in this study, that is, this population may have difficulties in understanding the information transmitted by health professionals.

Therefore, it is important to promote communicative strategies to promote better health care for patients living with HIV. Thus, it's up to health professionals to make health information accessible to populations with limited or inadequate $\mathrm{FHL}$, always aiming to health promotion.

\section{REFERENCES}

1. Nogueira LFR, Pellegrino P, Duarte AS, Inoue SRV, Marqueze LC. Common mental disorders are associated with higher viral load in people living with HIV. Saúde Debate. 2019;43(121):464-76. doi: https://doi. org/10.1590/0103-1104201912114

2. Freitas JP, Sousa LRM, Cruz MCMA, Caldeira NMVP, Gir E. Antiretroviral therapy: compliance level and the perception of HIV/Aids patients. Acta Paul Enferm. 2018;31(3): 327-33. doi: https://doi.org/10.1590/1982-0194201800046

3. Ministério da Saúde (BR). Secretaria de Vigilância em Saúde. Bol Epidemiol HIV AIDS 2019 dez [citado 2019 dez 4]; (nº esp). Disponível em: http://www.aids. gov.br/pt-br/pub/2019/boletim-epidemiologico-de-hivaids-2019

4. Goulart S, Meirelles BHS, Costa VT, Pfleger G, Silva LM. Adherence to antiretroviral therapy in adults with HIV/AIDS treated at a reference service. REME Rev Min Enferm. 2018;22:e-1127. doi: https://doi. org/10.5935/1415-2762.20180050 
5. Silva JAG, Dourado I, Brito AM, Silva CAL. Factors associated with non-adherence to antiretroviral therapy in adults with AIDS in the first six months of treatment in Salvador, Bahia State, Brazil. Cad Saúde Pública. 2015;31(6):188-98. doi: https://doi.org/10.1590/0102-311X00106914

6. Tufano CS, Amaral RA, Cardoso LRD, Malbergier A. The influence of depressive symptoms and substance use on adherence to antiretroviral therapy: a crosssectional prevalence study. São Paulo Med J. 2015;133(3):179-86. doi: https:// doi.org/10.1590/1516-3180.2013.7450010

7. Freitas MIF, Bonolo PF, Miranda WD, Guimarães MDC. Interactions and the antiretroviral therapy adherence among people living with HIV/Aids. REMERev Min Enferm. 2017; 21:e-1001. doi: https://doi.org/10.5935/1415-2762.20170011

8. Remor E, Milner-Moskovics J, Preussler G. Adaptação brasileira do "Cuestionario para la Evaluación de la Adhesión al Tratamiento Antiretroviral". Rev Saúde Pública. 2007;41(5):685-94. doi: https://doi.org/10.1590/S0034-89102006005000043

9. Marques SRL, Escarce AG, Lemos SMA. Health literacy and self-rated health in adults primary care patients. CoDAS. 2017;30(2):e20170127. doi: https://doi. org/10.1590/2317-1782/20182017127

10. Ministério da Saúde (BR). Secretaria de Vigilância em Saúde. Departamento de Vigilância, Prevenção e Controle das IST, do HIV/Aids e das Hepatites Virais. Relatório de monitoramento clínico do HIV. Brasília, DF: Ministério da Saúde; 2018 [cited 2019 Dec 10]. Disponível em: http://www.aids.gov.br/pt-br/ pub/2018/relatorio-de-monitoramento-clinico-do-hiv-2018

11. Maragno CAD, Mengue SS, Moraes CG, Rebelo MVD, Guimarães AMM, Pizzo TSD. Test of health literacy for portuguese-speaking adults. Rev. Bras Epidemiol. 2019;22:e190025. doi: https://doi.org/10.1590/1980-549720190025

12. Miyada S, Garbin AJl, Colturato R, Gatto J, Garbin CAS. Treatment adherence in patients living with HIV/AIDS assisted at a specialized facility in Brazil. Rev Soc Bras Med Trop. 2017;50(5):607-12. doi: https://doi. org/10.1590/0037-8682-0266-2017

\section{- Corresponding author:}

Taciane Alvarenga Perez

E-mail: taciperez@hotmail.com
13. Moraes DCA, Oliveira RC, Motta MCS, Ferreira OLC, Andrade MS. Antiretroviral therapy: the association between knowledge and the compliance. J Res: Fundam Care. 2015;7(4):3563-73. doi: https://doi. org/10.9789/2175-5361

14. Rocha PC, Lemos SMA. Conceptual aspects and factors associated with functional health literacy: a literary review. Rev (EFAC. 2016;18(1):214-25. doi: https://doi.org/10.1590/1982-021620161819615

15. Laws MB, Danielewicz M, Rana A, Kogelman L, Wilson IB. Health literacy in HIV treatment: accurate understanding of key biological treatment principles is not required for good ART adherence. AIDS Behav. 2015;19(4):635-44. doi: https:// doi.org/10.1007/s10461-014-0931-8

16. Phillips AL, Arya M. Raising awareness: the overlapping epidemics of low health literacy and HIV. J Assoc Nurses AIDS Care. 2016;27(4):372-5. doi: https://doi. org/10.1016/j.jana.2016.02.008

17. Menezes PDL, Alves NR, Diniz JA, Souza FAF, Carvalho PMM, Leite PIP. Grau de adesão à terapia tripla combinada antirretroviral em pacientes diagnosticados com HIV/ AIDS no Serviço de Atendimento Especializado. Rev Multi Psicol. 2019;13(44):811-27. doi: https://doi.org/10.14295/idonline. v13i44.1658

18. Pellowski JA, Kalichman SC, Grebler T. Optimal treatment adherence counseling outcomes for people living with HIV and limited health literacy. Ann Behav Med. 2016;42(1):39-47. doi: https://doi.org/10.1080/0896428 9.2014 .963006

19. Palumpo R. Discussing the effects of poor health literacy on patients facing HIV: a narrative literature review. Int J Health Policy Manag. 2015;4(7):417-30. doi: https://doi.org/10.15171/ijhpm.2015.95

20. Cunha GH, Galvao MTG, Pinheiro PNC, Vieira NFC. Health literacy for people living with HIV/Aids: an integrative review. Rev Bras Enferm. 2017;70(1):16777. doi: https://doi.org/10.1590/0034-7167-2015-0052

\section{Associate editor:}

Graziella Badin Aliti

Received: 02.07.2020

Approved: 06.01.2020

\section{Editor-in-chief:}

Maria da Graça Oliveira Crossetti 